\title{
Price stability vs. output stability: tales of federal reserve administrations
}

\author{
Umit Ozlale* \\ Department of Economics, Bilkent University, 06533 Bilkent, Ankara, Turkey
}

\begin{abstract}
This study disentangles policy parameters from those describing private sector behavior by simultaneously estimating an empirical model for inflation and output along with a loss function for the last three Federal Reserve administrations. Three important results emerge: First, the Federal Reserve appears to put more emphasis on price stability than output stability when the entire sample is considered. Second, and more importantly, the loss function parameters exhibit structural break at the time Paul Volcker was appointed chairman. The accommodative characteristics of monetary policy were replaced with a more active policy towards controlling inflation. Finally, interest rate smoothing is found to be an important feature of the monetary policymaking process for all three administrations. (C) 2002 Elsevier Science B.V. All rights reserved.
\end{abstract}

JEL classification: E52; E58; E61

Keywords: Monetary policy; Federal reserve; Optimal linear regulators

\section{Introduction}

Since the late 1960s, the United States economy experienced two different sorts of macroeconomic performances. Until the early 1980s, high and volatile inflation existed with several recessions. However, in the last two decades, inflation remained low and steady, with favorable output growth. The studies that offer explanations of these two different episodes can be classified in two groups. First, some economists view supply shocks as the main determinant of the two different macroeconomic performances. As pointed out by Hamilton (1983), the two major oil shocks in 1973 and 1979 could be the driving forces of both the high inflation and the recessions. After the 1980s, the supply shocks were mostly positive, which helped the policymakers to sustain low and

* Tel.: +90-312-290-1584; fax: +90-312-266-5140.

E-mail address: ozlale@bilkent.edu.tr (U. Ozlale). 
stable inflation, with high output growth. However, recent studies cast some doubt on this view. DeLong (1997) argues that high inflation was already a problem before the oil crises. Even though the increases in oil prices may explain the transitory movements in inflation, they cannot explain the persistent inflationary environment of the 1970s. Bernanke et al. (1997) examine the post-1980 era and find that the decrease in inflation in this period appears to lead the decrease in the real oil price.

The second view stresses the importance of the conduct of monetary policy. Recent empirical studies find substantial differences in the conduct of monetary policy between the pre-1979 and post-1979 era's. Clarida et al. (2000) estimate a forward-looking monetary policy reaction function and find significant differences in the estimated policy rule across periods. Judd and Rudebusch (1998) estimate a Taylor-type (1993) reaction function and report that monetary policy may have changed in significant ways over time. A common feature of these studies is that the response of the interest rate, which is the main monetary policy instrument, to an increase in inflation was relatively weak during Arthur Burns administration and the short tenure of G. William Miller. However, interest rate policy in the Volcker and Greenspan periods seems to be much more sensitive to changes in both actual and expected inflation.

Another common characteristic of these two empirical studies is that they focus only on the estimation of ad hoc monetary policy reaction functions. These studies leave open the question of whether the instabilities will continue to appear when the reaction function is estimated as part of a complete macroeconometric model. To answer this question, this study takes a broader view taking the structural model of inflation and output by Rudebusch and Svensson $(1998,1999)$ as its starting point. It goes beyond their studies by simultaneously estimating the empirical model for the macroeconomy and a loss function for the monetary policy for each of the three Federal Reserve administrations. Such an estimation method identifies independently the behavior of the private economy from those describing the Federal Reserve policy parameters, and it addresses the Lucas' critique by testing stability directly for policy parameters and structural parameters. ${ }^{1}$

Three important results emerge from this exercise. First, it is found that more emphasis has been put on price stability than output stability when the entire sample is considered. Second, and more importantly, the parameters of the loss function are not stable between the Burns period and the Volcker-Greenspan period. During the Burns administration, output stability was a superior goal in the monetary policymaking process. However, during the Volcker and Greenspan period, price stability has been much more important. ${ }^{2}$ Finally, it has been found that interest rate smoothing has always been an important goal for the Federal Reserve, regardless of the administrations.

In earlier work, Salemi (1995) obtains similar results. Unlike Salemi's unconstrained VAR, however, the model presented here adds restrictions that give each equation a structural interpretation. This difference allows us to focus not only on the possibility of instability in the Federal Reserve's policy preferences, but also on the possibility of instability in the structural equations describing the behavior of the private sector. In

\footnotetext{
${ }^{1}$ Another study in this field is done by Favero and Rovelli (2000).

${ }^{2}$ The Miller administration has been excluded because of his short tenure.
} 
other words, our model can do a more careful job of disentangling instability in the Federal Reserve's preferences from instability in the behavior of private-sector agents.

The plan of this paper is as follows. The next section introduces the empirical model of inflation and output along with a loss function for the monetary policymaker. Section 3 describes the estimation procedure and the optimization problem used in this study. Section 4 presents the parameter estimates, and the policy function and evaluates the empirical fit of the model. Then, parameter stability tests are performed, and differences in the parameters of the loss function are analyzed. Section 5 summarizes the findings.

\section{The model and the loss function}

\subsection{The empirical model of inflation and output}

As mentioned above, this study adopts the empirical model used in Rudebusch and Svensson $(1998,1999)$. The two equations for output and inflation are

$$
\begin{aligned}
& \pi_{t+1}=\alpha_{\pi 1} \pi_{t}+\alpha_{\pi 2} \pi_{t-1}+\alpha_{\pi 3} \pi_{t-2}+\alpha_{\pi 4} \pi_{t-3}+\alpha_{y} y_{t}+\varepsilon_{t+1}, \\
& y_{t+1}=\beta_{y 1} y_{t}+\beta_{y 2} y_{t-1}-\beta_{r}\left(\bar{i}_{t}-\bar{\pi}_{t}\right)+\eta_{t+1} .
\end{aligned}
$$

In Eqs. (1) and (2), $\pi_{t}$ is the annualized quarterly inflation rate, i.e., $\pi_{t}=400\left[\ln \left(P_{t}\right)-\right.$ $\left.\ln \left(P_{t-1}\right)\right]$, where $P_{t}$ is the chain-weighted price index. $\bar{\pi}_{t}$ is the average inflation over the preceding four quarters. $y_{t}$ is the output gap measured on the log of real GDP, with a quadratic trend removed. Such a measure was previously used by Clarida et al. (1997). ${ }^{3}$ Furthermore, the sum of the lagged inflation coefficients in Eq. (1) is assumed to be equal to one (i.e. $\sum_{i=1}^{4} \alpha_{\pi i}=1$ ), implying that there is no long-run trade-off between output and inflation. ${ }^{4}$ Besides, $i_{t}$ is the quarterly average funds rate, and $\bar{i}_{t}$ is the four-quarter average funds rate. All the variables are de-meaned, therefore no constants appear, and average real interest rate is set to zero. ${ }^{5}$

Eq. (1) can be viewed as an Aggregate Supply curve, while Eq. (2) is an Aggregate Demand curve. Thus, the model is a backward-looking Keynesian model, in which the monetary policy affects the real economy only with a lag. Inflation is explained by its lagged values and lagged output gap. Although the empirical success of the model is convincingly documented by Rudebusch and Svensson (1998, 1999), it is useful to discuss the advantages and disadvantages of the general approach here.

Backward-looking models receive support from both academic economists and policymakers. Fuhrer (1997) tests a backward-looking model against a forward-looking version, and his results are in favor of the former. Moreover, Blinder (1998) states his preferences in favor of backward-looking models.

The model is a simple linear one, which consists of two basic equations. Yet, it must be noted that it is rich enough to capture the dynamics of output and inflation. In fact, the model can be thought as two restricted equations from a trivariate vector

\footnotetext{
${ }^{3}$ See Cogley (1997) for various measures of potential output and output gap.

4 The results did not change when this constraint was relaxed.

${ }^{5}$ The starting date coincides with the appointment of Arthur Burns as the chairman of the Federal Reserve.
} 
autoregression (VAR) model with four lags. ${ }^{6}$ In the fourth section, after the parameters are estimated, the Akaike information criteria (AIC) and Schwarz information criteria (SIC) of the model are compared with an unrestricted VAR model, and it is shown that the model employed here seems to be favored by the information criteria. One interesting result is that the model also fits for other industrialized countries' data surprisingly well. This feature of the model makes it attractive to employ it for cross-section analysis.

The model's depiction of policy is also consistent with previous studies. The operating procedure for the US monetary authority is through the federal funds rate, which is consistent with the findings of Bernanke and Mihov (1998). Goodfriend (1991) also argues that, the funds rate had been the implicit target for the Federal Reserve even under the period of official reserve targeting. The reasoning behind Taylor's (1993) rule is also implicitly captured in this model: when the output gap is positive and puts an upward pressure on inflation, the Federal Reserve can bring inflation back down by increasing the nominal interest rate sufficiently enough to push up the real interest rate. $^{7}$

On the other hand, the model can be criticized for being too simplistic, and glossing over many important characteristics of the monetary transmission mechanism. Also, Lucas' critique may apply since the model is backward-looking. To allay these concerns it is helpful to apply econometric stability tests. ${ }^{8}$ In this context, two stability teststhe Likelihood Ratio test and Wald statistic - are performed, and it is shown that the empirical model presented above is stable across periods.

\subsection{The loss function for the monetary authority}

In this section, a simple loss function for the monetary authority is defined as

$$
L_{t}=\lambda_{\pi}\left(\bar{\pi}_{t}\right)^{2}+\lambda_{y}\left(y_{t}\right)^{2}+\lambda_{i}\left(i_{t}-i_{t-1}\right)^{2},
$$

where all the weights are assumed to be greater than zero, i.e., $\lambda_{\pi}>0, \lambda_{y}>0$ and $\lambda_{i}>0$. Furthermore, the sum of the weights is assumed to be equal to one, i.e., $\lambda_{\pi}+$ $\lambda_{y}+\lambda_{i}=1$.

The first two terms imply that the monetary authority is penalized when average inflation and the output gap deviate from their target levels, which are zero. The third term represents the interest rate smoothing incentive for the policymaker. Since Barro and Gordon (1983), such a loss function formulation has become quite common. After Rogoff (1985) proved that better outcomes are achieved by a conservative Central

\footnotetext{
${ }^{6}$ Actually, the model presented here is within the same spirit with the 11 Central Bank models analyzed in the Bank for International Settlements (1995).

${ }^{7}$ Clarida et al. (2000) finds that, in the pre-Volcker years, the Federal Reserve was accommodative in the sense that it increased the nominal interest rates by less than the increase in the expected inflation. However, during Volcker-Greenspan period, the Federal Reserve had increased both nominal and the real interest rates in response to higher expected inflation.

${ }^{8}$ Rudebusch and Svensson $(1998,1999)$ show that the model employed in this study passes the stability tests easily for United States.
} 
Banker who puts more emphasis on price stability than output stability $\left(\lambda_{\pi}>\lambda_{y}\right)$, an independent Central Banker has been associated with a high $\lambda_{\pi} / \lambda_{y}$ ratio. ${ }^{9}$

There are several reasons to include an interest rate smoothing incentive in the loss function. In practice, it has been observed that the Federal Reserve adjusts interest rates more smoothly than the conventional monetary models would predict. As an example, the FRB-US model predicts a more volatile interest rate path than the policymakers would choose. This is also confirmed in Rotemberg and Woodford (1997). Although the smoothing incentive for the policymakers remains something of a mystery, there are several explanations in this context. Clarida et al. (1999) suggest that, model and parameter uncertainty may induce policymakers to have a smoothing incentive. Rotemberg and Woodford (1997) analyze the lagged dependence of interest rates and find that such a behavior enables Central Banks to manipulate aggregate demand with more modest movements in the short-term interest rate. Another reason for a smoothing incentive is to ensure the existence of well-functioning capital markets. Volatile interest rates may result in capital losses, which would be disruptive for the financial sector.

\section{Estimation and optimization}

As mentioned in the first section, there are two purposes of this study. The first goal is to estimate the parameters of the loss function and the empirical model represented in the previous section. The second purpose is to see whether there have been structural breaks for the parameters of the model and the loss function between Federal Reserve administrations. This section describes the optimization procedure and the estimation method used to obtain these parameters.

\subsection{The optimization problem for the policymaker}

The intertemporal loss function for the policymaker at time $t$ is

$$
E_{t}(1-\beta) \sum_{\tau=0}^{\infty} \beta^{\tau} L_{t+\tau},
$$

where $\beta$ is the discount factor and $L_{t}$ is the period loss function for the policymaker. As $\beta \rightarrow 1$, the intertemporal loss function approaches $E\left(L_{t}\right)$ which will be equal to $\lambda_{\pi}\left(\bar{\pi}_{t}\right)^{2}+\lambda_{y}\left(y_{t}\right)^{2}+\lambda_{i}\left(i_{t}-i_{t-1}\right)^{2}$.

After the empirical model is recast in state space representation, the problem for the policymaker becomes a stochastic optimal linear regulator problem, like those discussed by Sargent (1987) and Ljungqvist and Sargent (2000). Minimizing the objective function with respect to the state equation results in a policy reaction function

$$
i_{t}=-f X_{t}+\xi_{t},
$$

where $f$ is a row vector and $X_{t}$ is the state vector. $\xi_{t}$ can be thought as a policy shock, introduced to pick up movements in the interest rate that cannot be explained

\footnotetext{
${ }^{9}$ One extension to this study could be to compare this ratio for several countries and generate an empirical Central Bank Independence index.
} 
Table 1

Parameter estimates of the inflation equation

\begin{tabular}{lcc}
\hline Parameter & Estimate & Standard error \\
\hline$\alpha_{\pi 1}$ & 0.76 & 0.081 \\
$\alpha_{\pi 2}$ & -0.40 & 0.103 \\
$\alpha_{\pi 3}$ & 0.42 & 0.097 \\
$\alpha_{\pi 4}$ & 0.22 & 0.065 \\
$\alpha_{y}$ & 0.17 & 0.026 \\
$\sigma_{\varepsilon}$ & 0.67 & 0.053 \\
$\sigma_{\varepsilon \eta}$ & 0.11 & 0.039 \\
\hline
\end{tabular}

by the model. Common sense tells us that Federal Reserve officials have not, at any time in the past, followed a mechanical rule for setting the short-term nominal interest rate. In addition, including a policy shock will allow us to obtain impulse responses for each of the three shocks: the policy shock, the aggregate supply shock, and the aggregate demand shock. Therefore, we will better evaluate the model's overall fit, and see whether the obtained impulse responses will display the "prize puzzle"-increasing prices in response to a monetary policy contraction, as documented by Gordon and Leeper (1994), Leeper et al. (1996) and Christiano et al. (1998).

Finally, substituting the feedback rule into the state equation and the equation for the goal variables yields an optimal closed-loop system, which shows the evolution of the state variables under the optimal control.

\subsection{The estimation procedure}

After deriving the optimal closed-loop system, the parameters of the model and their standard errors can be estimated by initializing the Kalman filter and maximizing the log-likelihood function, as discussed in Hamilton (1994). The standard errors of the parameters can be obtained by taking the square roots of the diagonal elements of the inverse of the information (Hessian) matrix.

\section{Parameter estimates}

\subsection{Estimation of the empirical model}

As explained above, the sample period is 1970:Q1-1999:Q1. The parameter estimates for the empirical model of inflation and output along with their standard errors are presented in Tables 1 and 2 .

When the parameter estimates are compared to Rudebusch and Svensson (1998, 1999), there are only slight differences. One obvious reason is the difference in the sample period used. The second factor may be the estimation technique. They estimate each equation by OLS. In this study, the parameters of the model and the loss function are simultaneously estimated so that the log-likelihood function is maximized. 
Table 2

Parameter estimates of the output equation

\begin{tabular}{lcc}
\hline Parameter & Estimate & Standard error \\
\hline$\beta_{y 1}$ & 1.19 & 0.081 \\
$\beta_{y 2}$ & -0.16 & 0.076 \\
$\beta_{r}$ & -0.09 & 0.024 \\
$\sigma_{\eta}$ & 0.17 & 0.086 \\
$\sigma_{\varepsilon \eta}$ & 0.11 & 0.039 \\
\hline
\end{tabular}

Table 3

Model selection criteria

\begin{tabular}{|c|c|c|c|c|c|}
\hline \multicolumn{3}{|c|}{ Inflation equation } & \multicolumn{3}{|c|}{ Output equation } \\
\hline & VAR & The model & & VAR & The model \\
\hline SIC & 2.55 & 2.37 & SIC & 9.78 & 9.36 \\
\hline AIC & 2.35 & 2.30 & AIC & 9.56 & 9.23 \\
\hline
\end{tabular}

Overall, the parameter estimates of the two studies are close, and each parameter has the expected sign.

After deriving the estimates, it is necessary to evaluate the empirical fit of the model. Comparing the model with an unrestricted VAR model can fulfill this purpose. Although VAR models are criticized for their lack of structure, they provide a useful benchmark for the empirical performance of the models. Actually, the model presented in this paper can be seen as two restricted equations from a trivariate VAR with four lags. Table 3 represents the Akaike information criteria (AIC) and Schwarz information criteria (SIC) of the two models.

For both the equations, the model presented here has lower SIC and AIC values. As a result, the model represented here seems to be favored by the information criteria. ${ }^{10}$

A second method used in this context was to perform an $F$-test to test the restrictions of the model presented here. The results are in favor of our model: the restrictions implied by the model cannot be rejected. As mentioned in the first section, Lucas' critique can apply for backward-looking models, which makes it desirable to perform stability tests as well. The two tests which will be applied for this purpose is the Likelihood Ratio test described in Andrews and Fair (1988), and the Wald statistic. After performing the two procedures for all of the possible break points, the null hypothesis cannot be rejected for the estimated parameters. ${ }^{11}$ Therefore, the model's parameters are reasonably stable across the sample period.

\footnotetext{
${ }^{10}$ This result is found also by Rudebusch and Svensson (1998) for the inflation equation. The AIC value for the output equation in their study is higher, however.

${ }^{11}$ Rudebusch and Svensson $(1998,1999)$ find the same result. Although they employ a larger sample, they find that the model is stable across periods.
} 
Table 4

Parameter estimates of the loss function

\begin{tabular}{llc}
\hline Parameter & Estimate & Standard error \\
\hline$\lambda_{\pi}$ & 0.39 & 0.016 \\
$\lambda_{y}$ & 0.26 & 0.012 \\
$\lambda_{i}$ & 0.35 & 0.017 \\
\hline
\end{tabular}

\subsection{Estimation of the loss function}

The loss function for the monetary authority was as follows:

$$
L_{t}=\lambda_{\pi}\left(\bar{\pi}_{t}\right)^{2}+\lambda_{y}\left(y_{t}\right)^{2}+\lambda_{i}\left(i_{t}-i_{t-1}\right)^{2},
$$

where $\lambda_{\pi}, \lambda_{y}$, and $\lambda_{i}$ reflect the weights on price stability, output stability and interest rate smoothing, respectively.

The parameter estimates of the function can be seen in Table 4 .

Table 4 indicates that the Federal Reserve has put more weight on price stability than output stability when the entire sample period is considered. The interest rate smoothing incentive for the policymaker has been almost as important as the price stability objective.

The stability of the loss function parameters can also be tested with the same methods described above. Here, possible break points are chosen according to the date of appointments of the chairmen of the Federal Reserve. These dates are 1979:3, which is the beginning of the Volcker period, and 1987:Q3, the appointment of Alan Greenspan.

Both the Likelihood Ratio test suggested by Andrews and Fair (1988) and the Wald statistic reveal the same result: there was a structural break for the loss function parameters between Burns period and Volcker period. The Likelihood Ratio test statistic is 19.31 while the Wald test statistic is 14.12 . The critical value at the 95 percent significance level with 3 degrees of freedom is 7.82 . Therefore, the null hypothesis of stability is easily rejected. On the other hand, when the beginning of the Greenspan period is chosen as the possible break point, the Likelihood Ratio test statistic is 3.11 while the Wald statistic is 2.92 , which are both smaller than the critical value 7.82 . Therefore, the null hypothesis cannot be rejected. ${ }^{12}$ Consequently, the stability tests for the loss function parameters imply that there was a significant change in the weights attached to goal variables after the appointment of Paul Volcker.

\subsection{Parameter estimates under three administrations}

The results in the previous sections imply that the price stability has been a more important goal for the Federal Reserve than output stability in the last three decades,

\footnotetext{
${ }^{12}$ Another tested breakpoint was 1982:Q4, since from the start of the Volcker administration to this date, the Federal Reserve targeted non-borrowed reserves, and this period was characterized by a sharp disinflation. However, there were no signs of instability.
} 
Table 5

Loss function parameter estimates

\begin{tabular}{llll}
\hline & $\lambda_{\pi}$ & $\lambda_{y}$ & $\lambda_{i}$ \\
\hline Burns period (1970:1-1978:1) & 0.33 & 0.37 & 0.30 \\
& $(0.019)$ & $(0.038)$ & $(0.036)$ \\
Volcker period (1979:3-1987:2) & 0.45 & 0.21 & 0.34 \\
Greenspan period (1987:3-1999:1) & $(0.012)$ & $(0.009)$ & $(0.018)$ \\
Volcker-Greenspan period (1979:3-1999:1) & 0.42 & 0.22 & 0.36 \\
& $(0.026)$ & $(0.044)$ & $(0.037)$ \\
Whole sample (1970:1-1999:1) & 0.43 & 0.21 & 0.36 \\
& $(0.022)$ & $(0.016)$ & $(0.025)$ \\
& 0.39 & 0.26 & 0.35 \\
\end{tabular}

while interest rate smoothing has also been an important factor. More importantly, even though the empirical model and its parameters are found to be stable across periods, there was a structural break in the loss function parameters at the time when Paul Volcker was appointed as the chairman.

As it was mentioned in the first section, several studies attempted to explain the different inflation performances of the United States in the last three decades. Some economists like Hamilton (1983) argue that the existence of negative supply shocks in 1970s resulted in high and volatile inflation, while the positive supply shocks helped the Federal Reserve to sustain low inflation with a high economic growth rate. Other studies, including Clarida et al. (2000), and Judd and Rudebusch (1998), find important differences in the way monetary policy was conducted in the pre-Volcker and post-Volcker period. Motivated by these studies and the findings of the previous section about the structural break for the loss function parameters, this section estimates the parameters of the loss function under each of the three administrations: Burns (1970:Q1-1978:Q1), Volcker (1979:Q3-1987:Q2) and Greenspan (1987:Q3-1999:Q1).

The loss function parameter estimates along with their standard errors for the three periods are presented in Table 5.

Table 5 displays a very important result: More emphasis was placed on output stability during Burns administration, while price stability was the dominant goal in the post-Volcker period. This can be seen most clearly by comparing the $\lambda_{\pi} / \lambda_{y}$ ratios across periods: the ratio is 0.89 for the Burns period, 2.14 for the Volcker period and 1.91 for the Greenspan period. This result confirms the findings of the previous studies which found a significant change in the way that monetary policy is implemented. An accommodative policy was followed under Burns administration, while achieving price stability has been the main focus of monetary policy under Volcker and Greenspan administrations. Another important finding is that interest rate smoothing incentive has remained an important goal in monetary policymaking under all administrations. 


\subsection{The policy functions}

The parameter estimates of the model and the loss function imply that the feedback instrument rule mentioned in the previous section is

$$
\begin{aligned}
i_{t}= & 0.77 \pi_{t}+0.24 \pi_{t-1}+0.21 \pi_{t-2}+0.19 \pi_{t-3}+1.19 y_{t} \\
& -0.17 y_{t-1}+0.70 i_{t-1}-0.13 i_{t-2}-0.06 i_{t-3} .
\end{aligned}
$$

This rule implies that Federal Reserve policy responds contemporaneously to movements in inflation and the output gap in a very active way: a 1 percent increase in inflation leads to a 0.77 percent increase in the interest rate, and a 1 percent increase in the output gap leads to a 1.19 percent increase in the interest rate. Federal Reserve also takes the past values of inflation into account, although its response is smaller compared to the response of current inflation and output gap. Another important feature is the lagged dependence of the interest rate, an outcome that reflects the interest rate smoothing motive.

It is useful to compare the reaction function obtained above with a generalized Taylor rule presented in Rudebusch and Svensson (1999), in which the weights in the loss function are $\lambda_{\pi}=0.4, \lambda_{y}=0.4$ and $\lambda_{i}=0.2$. Such a reaction function is

$$
\begin{aligned}
i_{t}= & 0.86 \pi_{t}+0.31 \pi_{t-1}+0.37 \pi_{t-2}+0.12 \pi_{t-3}+1.34 y_{t} \\
& -0.35 y_{t-1}+0.50 i_{t-1}-0.06 i_{t-2}-0.03 i_{t-3} .
\end{aligned}
$$

In both reaction functions, the coefficient signs are the same. However, in Rudebusch and Svensson's simulated reaction function, the Federal Reserve responds to inflation and output gap more vigorously. The main reason for this difference is the weights attached to goal variables in the loss function. This factor also explains the different lagged dependence of interest rates in the two reaction functions.

Based on the subsample estimates, policy rules for the pre-Volcker and post-Volcker periods are

$$
\begin{aligned}
\text { pre-Volcker : } i_{t}= & 0.63 \pi_{t}+0.19 \pi_{t-1}+0.11 \pi_{t-2}+0.20 \pi_{t-3}+1.29 y_{t} \\
& -0.12 y_{t-1}+0.64 i_{t-1}-0.06 i_{t-2}-0.08 i_{t-3}, \\
\text { post-Volcker : } i_{t}= & 0.81 \pi_{t}+0.23 \pi_{t-1}+0.22 \pi_{t-2}+0.15 \pi_{t-3}+1.14 y_{t} \\
& -0.17 y_{t-1}+0.75 i_{t-1}-0.09 i_{t-2}-0.07 i_{t-3} .
\end{aligned}
$$

As the two policy functions show, the interest rate response to current inflation is considerably higher in the post-Volcker regime. The Federal Reserve takes a more active role in controlling inflation in this period. The response of interest rate to output is slightly higher in Burns administration.

These results for the policy functions are consistent with Clarida et al. (2000). Along with their original forward-looking specification, they also present backward-looking estimates for the monetary policy reaction function. Although the magnitudes of the interest rate response are different, both their study and ours find a more active policy 


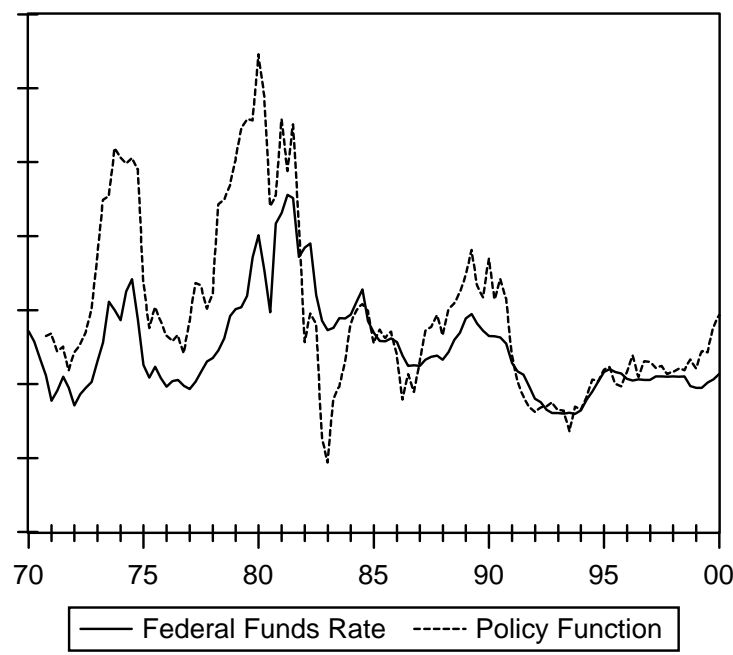

Fig. 1. Interest rate and policy function.

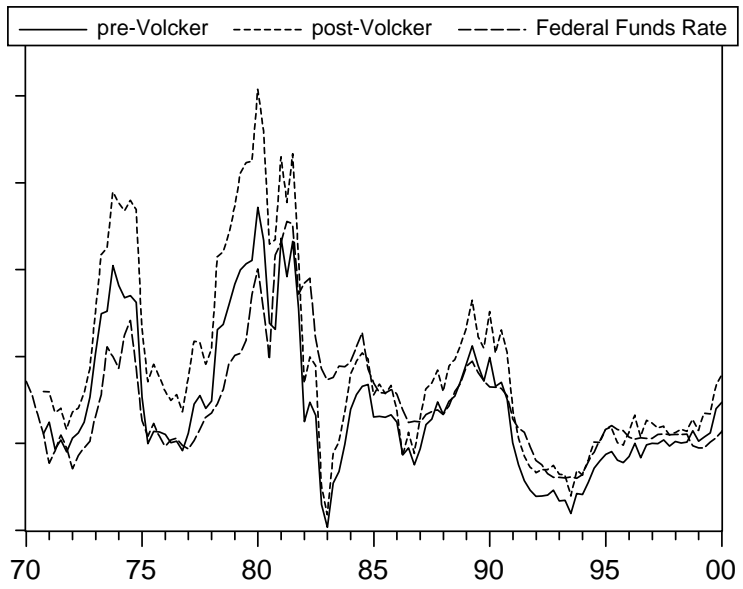

Fig. 2. Interest rate and policy regimes.

towards controlling inflation in the post-Volcker regime, and a response of interest rates to the output gap, that is slightly higher in the Burns period.

\subsection{Simulations}

Simulations derived from the policy functions for the entire sample, the pre-Volcker period and the post-Volcker period can be seen in Figs. 1 and 2. In Fig. 1, the actual interest rate path is compared to the path implied by the estimated policy function 
for the entire sample. Although movements in the two paths are similar, the policy function predicts a higher interest rate than the actual one in the pre-Volcker regime.

Similarly, Fig. 2 compares the actual interest rate to those implied by the estimated policy functions for the pre-Volcker regime and the post-Volcker regime. Before 1980, the policy function for the pre-Volcker regime and the actual interest rate are close to each other. The post-Volcker regime consistently predicts a higher interest rate for this period, which again implies that monetary policy in this regime has been more aggressive. After 1980, this situation is almost completely reversed. Excluding the period between 1990 and 1994, the actual interest rate and the post-Volcker regime follow a similar path while the pre-Volcker regime predicts a lower interest rate. As a result, the two figures support the findings of the previous sections.

\subsection{Impulse responses and variance decompositions}

As mentioned before, impulse response functions and variance decompositions will allow us to evaluate the model's overall fit. The impulse responses to each of the three shocks, the policy shock, the aggregate supply shock and the aggregate demand shock can be seen in Fig. 3. One important result is that the impulse response functions show no sign of a "prize puzzle"-increasing prices in response to a monetary policy contraction: a contractionary policy shock causes both inflation and output to fall, as expected. Also, a contractionary supply shock causes interest rates to increase and output to decrease over 10-year horizons. Finally, a positive aggregate demand shock causes all of the variables to increase, which is consistent with the literature.

Variance decompositions reveal that policy behavior is to a large extent endogenous. Over horizons of 1-5 yr, around 25 percent of the fluctuations in the funds rate are due to aggregate demand shocks and 40 percent of the shocks are due to aggregate supply shocks. Another finding is that aggregate demand and policy disturbances are important sources of inflation variation, each around 30 percent over horizons of 5 years. Finally, policy shocks are very important determining output gap fluctuations, accounting for 65 percent of the fluctuations.

\section{Conclusion}

During the 1970s, the United States economy suffered from high and persistent rates of inflation and slow rates of growth. From the beginning of 1980s the story was completely reversed: low inflation was sustained with higher levels of economic growth. Some studies, most recently Clarida et al. (2000), claim that the conduct of monetary policy played an important role in generating these differences. Before 1980s, monetary policy was characterized as being more accommodative. However, since the beginning of Volcker administration, controlling inflation and achieving price stability has been the most important goal.

This study adopts a simple empirical model of inflation and output from Rudebusch and Svensson (1998, 1999), defines a loss function for the monetary authority, and 
Response to One S.D. Innovations \pm 2 S.E. Response Of Inflation To A Contractionary Policy Shock

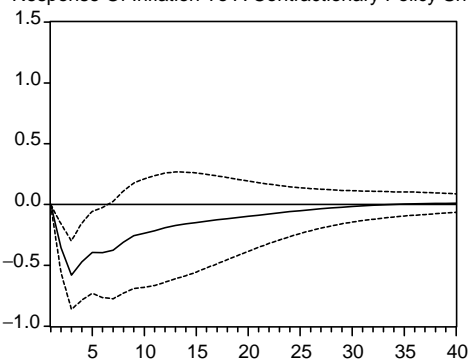

Response to One S.D. Innovations \pm 2 S.E. Response Of Output To A Contractionary Policy Shock

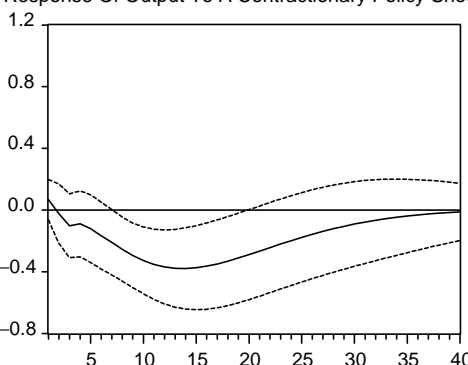

Response to One S.D. Innovations \pm 2 S.E. Response Of Interest Rate To A Contractionary Policy Shock

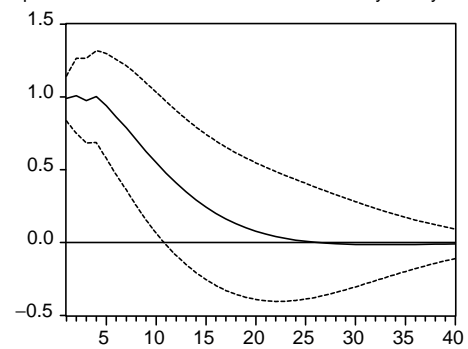

(a)

Response to One S.D. Innovations \pm 2 S.E. Response to One S.D. Innovations \pm 2 S.E. Response Of Inflation To A Contractionary Supply Shock Response Of Output To A Contractionary Supply Shock
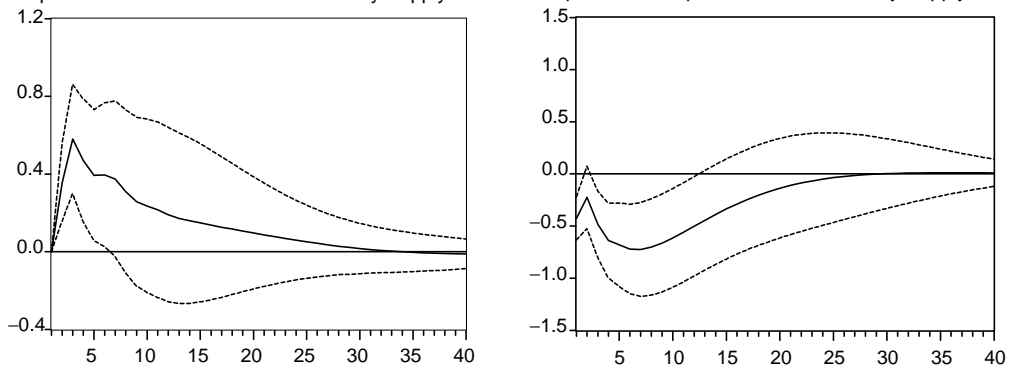

Response to One S.D. Innovations \pm 2 S.E.

Response Of Interest Rate To A Contractionary Supply Shock

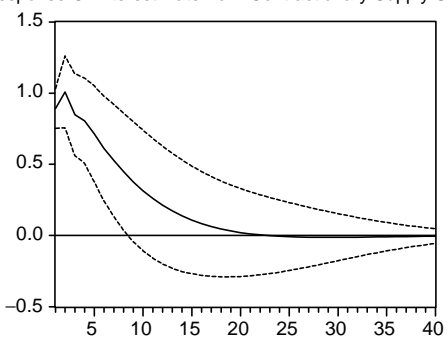

(b)

Fig. 3. Impulse response functions. (a) To a contractionary policy shock; (b) To a contractionary supply shock; (c) To an expansionary demand shock. 
Response to One S.D. Innovations \pm 2 S.E. Response Of Inflation To An Expansionary Demand Shock

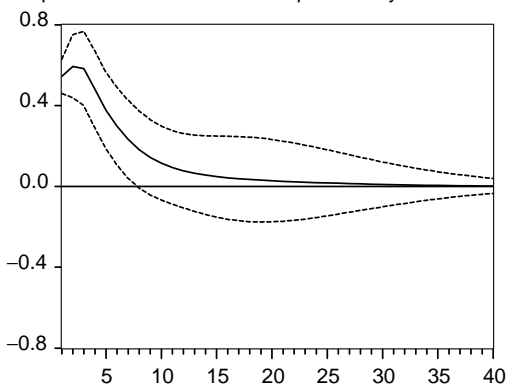

Response to One S.D. Innovations \pm 2 S.E. Response Of Output To An Expansionary Demand Shock

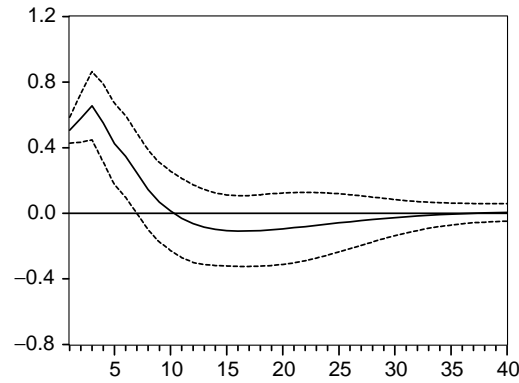

Response to One S.D. Innovations \pm 2 S.E. Response Of Interest Rate To An Expansionary Demand Shock

(c)

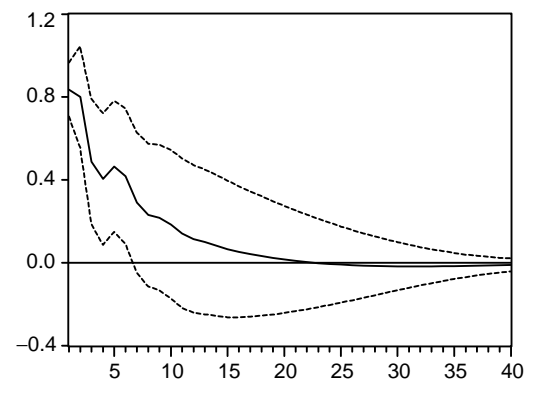

Fig. 3. (Continued).

simultaneously estimates the parameters for the model and the loss function. By doing so, the policy parameters are independently identified from those describing the behavior of the private economy. Also, monetary policy reaction functions associated with these estimated parameters are obtained both for the entire sample and the subsamples. It has been found that the empirical model's parameters are stable across the sample period, which is also consistent with Rudebusch and Svensson (1998, 1999). More interesting results are obtained when the estimates of the loss function parameters are considered. First, price stability has been a superior goal for the monetary policy when the whole sample is considered. Second, and more importantly, the loss function parameters are not stable throughout the sample. There is a structural break after Paul Volcker is appointed as chairman of the Federal Reserve. Output stability is found to play a more important role in the pre-Volcker era, while price stability has become much more dominant afterwards. The monetary policy reaction functions for the two periods also reflect these findings. The Volcker and Greenspan periods feature a more active stance toward controlling inflation. Based on these findings, this study supports the view that there has been an important change in the monetary policymaking process after the end of the 1970s.

One extension to this study would be to reproduce the results using a forward-looking variant of the model. In the forward-looking case, the optimization problem of the 
central bank becomes much more difficult to solve, requiring the special techniques described in Soderlind (1999). Thus, such an exercise is left for further research.

\section{Acknowledgements}

This paper owes much to my advisor, Peter N. Ireland. I am also grateful to Christopher Baum, Tommaso Monacelli, Fabio Schiantarelli, the seminar participants at Bilkent University, Boston College, Suffolk University, and two anonymous referees for their suggestions.

\section{References}

Andrews, D., Fair, R., 1988. Inference in nonlinear econometric models with structural change. Review of Economic Studies 55, 615-640.

Bank for International Settlements, 1995. Financial Structure and the Monetary Policy Transmission Mechanism, Basle, Switzerland.

Barro, R.J., Gordon, D.B., 1983. A positive theory of monetary policy in a natural rate model. Journal of Political Economy 91, 589-610.

Bernanke, B., Mihov, I., 1998. Measuring monetary policy. Quarterly Journal of Economics 113 (3), 869-902.

Bernanke, B., Gertler, M., Watson, M., 1997. Systematic monetary policy and the effects of oil price shocks. Brooking Papers on Economic Activity, pp. 91-157.

Blinder, A., 1998. Central Banking in Theory and Practice. MIT Press, Cambridge, MA.

Christiano, L., Eichenbaum, M., Evans, C.L., 1998. Monetary policy shocks: what have we learned and to what end? In: Taylor, J.B., Woodford, M. (Eds.), Handbook of Macroeconomics. Elsevier, Amsterdam.

Clarida, R., Gali, J., Gertler, M., 1997. Monetary rules in practice: some international evidence. NBER Working Paper no 6254

Clarida, R., Gali, J., Gertler, M., 1999. The science of monetary policy: a new Keynesian perspective. Journal of Economic Literature 1661-1707.

Clarida, R., Gali, J., Gertler, M., 2000. Monetary policy rules and macroeconomic stability: evidence and some theory. The Quarterly Journal of Economics 147-180.

Cogley, T., 1997. Evaluating non-structural measures of the business cycle. FRB San Francisco Economic Review 3, 3-21.

DeLong, J.B., 1997. America's peacetime inflation: 1970s. In: Romer, C., Romer, D. (Eds.), Reducing Inflation: Motivation and Strategy. University of Chicago Press, Chicago.

Favero, C.A., Rovelli, R., 2000. Modelling and identifying central bank preferences. Unpublished Working Paper, IGIER-Universita Bocconi, July 2000.

Fuhrer, J., 1997. The (un)importance of forward-looking behavior in price specifications. Journal of Money, Credit and Banking 29 (3), 338-350.

Goodfriend, M., 1991. Interest rates and conduct of monetary policy. Carnegie-Rochester Conference Series on Public Policy XXXIV, pp. 7-30.

Gordon, D.B., Leeper, E., 1994. The dynamic impacts of monetary policy: an exercise in tentative identification. Journal of Political Economy 102 (6), 1128-1247.

Hamilton, J., 1983. Oil price and the macroeconomy since World War II. Journal of Political Economy XCI, $228-248$.

Hamilton, J., 1994. Time Series Analysis. Princeton University Press, Princeton, NJ.

Judd, J.P., Rudebusch, G., 1998. Taylor's rule and the fed: 1970-1997. FRB San Francisco Economic Review 3, 3-16.

Leeper, E., Sims, C., Zha, T., 1996. What does monetary policy do? Brookings Papers on Economic Activity 2, 1-63. 
Ljungqvist, L., Sargent, T., 2000. Recursive Macroeconomic Theory. MIT Press, Cambridge, MA.

Rogoff, K., 1985. Optimal degree of commitment to an intermediate monetary target. The Quarterly Journal of Economics 100, 1169-1190.

Rotemberg, J., Woodford, M., 1997. An optimization-based econometric framework for the evaluation of monetary policy. In: Bernanke, B., Rotemberg, J. (Eds.), NBER Macroeconomics Annual, MIT Press, Cambridge, MA.

Rudebusch, G.D., Svensson, L.E.O., 1998. Policy rules for inflation targeting. NBER Working Paper no 6512.

Rudebusch, G.D., Svensson, L.E.O., 1999. Eurosystem monetary targeting: lessons from U.S. data. NBER Working Paper no 7179.

Salemi, M., 1995. Revealed preference of the federal reserve: using inverse-control theory to interpret the policy equation of a vector autoregression. Journal of Business \& Economic Statistics 13 (4), 419-433.

Sargent, T., 1987. Dynamic Macroeconomic Theory. Harvard University Press, Cambridge, MA.

Soderlind, P., 1999. Solution and estimation of RE macro models with optimal policy. European Economic Review 43, 813-823.

Taylor, J.B., 1993. Discretion versus policy rules in practice. Carnegie-Rochester Conference Series on Public Policy 39 , pp. 195-214. 